\title{
Az aszkézis módjai az Udumbarika-sutta három kínai fordításában
}

Az Udumbarika-sutta a páli nyelvü buddhista kánon, a Tipitaka ('Hármas kosár') Sutta-pitaka ('Beszédek kosara') egységében a legelső, 34 beszédből álló Dīghanikāya ('Hosszú beszédek gyüjteménye', DN) egységének 25. szövege (DN 25). ${ }^{1}$

A páli szövegben a vándoraszkétának (paribbājaka) ${ }^{2}$ nevezett Nigrodha az Udumbarikā asszony által vándoraszkétáknak fenntartott lakhelyen ( $p a-$ ribbājakârāma) tartózkodik aszkétatársaival együtt. Mikor Buddha egyik világi tanítványa, Sandhāna meglátogatja a hangoskodó és különféle világi témákról beszélgető aszkétákat, Nigrodha lecsendesíti a tömeget. Sandhāna megjegyzi az általa korábbról ismert Nigrodhának, hogy a hangoskodó aszkéták mennyire különböznek a pusztaság és az erdők magányába csendben visszahúzódó buddhista szerzetesektől, mire Nigrodha lekicsinylően szóvá teszi, hogy az ilyen periférián élö, vitákban részt nem vevő szerzeteseket, például Gotama szerzetest (samaṇa Gotama) könnyedén képes lenne legyőzni egy vitában, ha eljönne a közösségükbe. A beszélgetést csodálatos képességeivel a távoli Keselyü-csúcson is érzékelö Buddha lemegy a hegyről, és sétáló meditációba kezd a Sumāgadhā-folyó partján. Ekkor Nigrodha ismét lecsendesítve társait megszólítja Buddhát, hellyel kínálja, és megkérdezi tőle, hogy ő milyen módszerrel vezeti tanítványait. Buddha a kérdést a kettejük rendszerének jelentős különbségeire hivatkozva elhárítja, de késznek mutatkozik arra, hogy a Nigrodha és társai által gyakorolt aszkézisről beszéljen, így végül Nigrodha az aszkézis elégséges és elégtelen voltáról kérdezi Buddhát. Gotama ekkor sorolja fel a lent általunk vizsgálandó aszketikus gyakorlatokat, majd ezeket tökéletlennek (aparipuṇn̄a) nyilvánítva, mintegy 30 té-

\footnotetext{
Köszönöm Ruzsa Ferencnek, hogy jelen tanulmány első változatát elolvasta és kommentálta.

2 A parivrājaka páli megfelelőjét a Páli Kánonban nem használják a buddhista szerzetesekre, annak ellenére, hogy a köztudatban ebbe a kategóriába tartozhattak, vö. McGovern 2019: 157-158.
} 
telben hozzákezd ezek hiányosságainak (upakkilese) a kifejtéséhez. Ezek után Buddha felveti, hogy még ha valaki a 30 tételes listában szereplö potenciális hibákat nem is követi el, így ezekben tiszta (parisuddho) marad, még akkor sem ért el a végső lényegig. Ezután sorra veszi ez utóbbi eléréséhez vezető út állomásait, amelyek alapvetően megegyeznek a buddhista út fontosabb lépéseivel. Nigrodha elkeseredik, és belátja korábbi hibáit, majd Buddha felajánlja, hogy az elméletileg hétéves tanítás helyett mindössze hét nap alatt elmagyarázza és a végső célt felismerteti azzal, aki hozzá csatlakozik. Ezután elébe megy a beszéde elmondását rosszindulatúan magyarázó esetleges motivációknak, mint lehetséges vádaknak (pl. tanítványokat akar magának, azt kívánja, hogy feladják életmódjukat), és mindegyiket visszautasítja.

A theravāda hagyomány és a kínai buddhista kánonban fennmaradt, más iskolához tartozó szövegek összehasonlítása az utóbbi időben egyre fontosabb témává válik. ${ }^{3}$ A theravāda Udumbarika-suttának (I.) összesen három kínai változata létezik, amelyekből kettő bizonyíthatóan más buddhista irányzathoz tartozott. A három kínai szöveg a kínai buddhista kánonban maradt fenn:

II. Youtanpoluo jing 優昙婆邏經 [T01n0026]: Ez a szöveg a 152 szuttát tartalmazó Majjhimanikāyának megfelelö, szanszkrit nyelvü Madhyama-āgama gyüjtemény 222 szútrát tartalmazó kínai változatában (Zhong Ahan jing 中阿 含經, 'Közepesen hosszú āgamák') maradt fenn, amelyet a Sarvāstivāda iskolához tartozó, kasmíri Sanghadeva (Sengjiatipo 僧伽提婆) fordított a Keleti Jin-korban 東晉 (317-420), hozzávetőlegesen 397-398 körül egy másik kasmíri szerzetes, Sañgharakṣa által recitált szövegből. Maga a gyüjtemény is a fordító iskolájának alapvető hatását mutatja, ${ }^{4}$ a fordítás eredetije Karashima Seishi 辛嶋静志 szerint erősen szanszkritizált gāndhārī és prākrit nyelvű lehetett. ${ }^{5}$ A minket érdeklő, aszkézisről szóló rész háromszor jelenik meg a gyüjteményben, ${ }^{6}$ lényegében szó szerint ugyanabban a formában.

III. Santuona jing 散陀那經 [T01n0001p0047a17-49b25]: Ez a szútra a páli Dīghanikāya gyüjtemény szanszkrit megfelelöjének, a Dīrgha-āgama kínai fordításában szerepel. A kínai gyüjtemény (Chang Ahan jing 長阿含經, 'Hoszszú āgamák') a Dharmaguptaka (Fazangbu 法藏部) irányzat hagyományának

Ld. például Choong 2005; Anālayo 2011.

Anālayo 2017: 71.

Karashima 2017.

6 T01n0026p0441c17-0442a11, T01n0026p0592b06-c01, T01n0026p0712a25-b20. 
30 szövegét őrizte meg, és a fordítását Buddhayaśas (Fotuoyeshe 佛陀耶舍) és Zhu Fonian 笂佛念 készítette el a Kései Qin-dinasztiában (Hou Qin 後秦) i. sz. 413 körül, valószínüleg valamilyen középind (talán gāndhārī) eredeti alapján. A páli és a kínai mellett létezik egy VIII-X. szászadi kéziratban fennmaradt, töredékes szanszkrit változat is, amely a mūla-sarvāstivāda irányzathoz tartozhatott. $^{7}$

IV. Nijutuo fanzhi jing 尼拘陀梵志經 [T01n0011p0223a09-p0223b28]: Ez egy két tekercsből (juan) álló önálló fordítás, amelyet a Song-kori (960-1279) Shihu (Dānapāla) készített, aki 980-ban érkezett Udyānából Kaifengbe 開封, és jelentős mennyiségű szöveget fordított le kínaira, ${ }^{8}$ illetve részt vett a nyomtatott buddhista kánon sichuani kiadásának a munkálataiban is.

A páli szövegre I-gyel, a kínai szövegekre pedig a fent szereplő római számokkal hivatkozom, a kínai szöveg a Taishō-kánonból származik, de a központozását javítottam. A minket érdeklő részeket tematikus egységekre osztottam (1. Általános bevezető; 2. Étkezés; 3. Öltözék; 4. Egyéb; 5. Befejező rész), és így hasonlítom majd össze a különböző változatokat. A fenti leírás történéseibe ott kapcsolódunk be, amikor Nigrodha kérdésére Buddha úgy kíván válaszolni, hogy kijelenti, inkább az aszkéták gyakorlatának elégséges, illetve elégtelen voltáról beszélne, semmint saját tanításáról.

\section{A kínai fordítások összehasonlítása}

\section{I/1. ÁLTALÁNOS BEVEZETŐ (DN 25)}

„Nigrodha, nehéz számodra ezt megérteni, mivel más a nézeted (dițthi), más az álláspontod (khanti), más a hajlandóságod (ruci), más a gyakorlatod (āyoga) és más a mestered (ācariya). (...) Kérlek, a saját hagyományod lemondásáról (adhijeguccha) tegyél fel kérdést nekem: 'Ó uram, mennyiben tökéletes és mennyiben tökéletlen az önsanyargatás (tapojigucchā)?' Mikor így szólt, a vándoraszkéták nagy lármával és hangoskodással így szóltak: '

Hartmann 2014.

A Shihu fordításai közé számító müvek listáját ld. Nanjio 1883: 453-455.

A páli szöveg magyar fordítását a rendelkezésemre álló két angol verzió (Rhys Davids, Sujato) alapján készítettem a páli szöveg figyelembevételével. Ruzsa Ferencnek köszönöm, hogy a fordítást ellenőrizte. 
Milyen csodálatos! Milyen meglepö! Gotama szerzetesnek (samaṇa) hatalmas (mágikus) képessége (mahiddhika) van, óriási hatalommal (mahānubhāva) rendelkezik, hiszen saját tanítását félreteszi és más tanításá(nak megtárgyalására) hív fel.' Ekkor Nigrodha vándoraszkéta a többi vándoraszkétát lecsendesítve így szólt a Magasztoshoz: 'Uram, „a mi gyakorlatunk tana az aszketikus lemondás, lényege az aszketikus lemondás, az aszketikus lemondáshoz kötődik." Ó uram, mikor tökéletes és mennyiben tökéletlen az önsanyargatás (tapojigucchā)?'

Dujjānaṃ kho etaṃ, nigrodha, tayā aññadiț̣hikena aññakhantikena aññarucikena aññatrâyogena añnatrâcariyakena (...) Ingha tvạ̣ maṃ, nigrodha, sake ācariyake adhijegucche pañham puccha: 'katham santā nu kho, bhante, tapojigucchā paripuṇnā hoti, katham aparipuṇnā̄"'ti? Evaṃ vutte, te paribbājakā unnādino uccāsaddamahāsaddā ahesuṃ: "acchariyam vata bho, abbhutam vata bho, samaṇassa gotamassa mahiddhikatā mahânubhāvatā, yatra hi nāma sakavādaṃ țhapessati, paravādena pavāressatî̀'ti. Atha kho nigrodho paribbājako te paribbājake appasadde katvā bhagavantam etadavoca: "mayam kho, bhante, tapojigucchāvādā tapojigucchāsārā tapojigucchāallīnā viharāma. Katham santā nu kho, bhante, tapojigucchā paripuṇṇā hoti, kathaṃ aparipuṇn̄ā’ti?

\section{II/1. ÁLTALÁNOS BEVEZETŐ (T01n0026: 優曇婆邏經)}

„A Világ tiszteltje megértette és így szólt: 'Nigrodha, az én tanításom rendkívül mély, rendkívül csodálatos, rendkívül különleges. Nehéz felismerni, nehéz megismerni, nehéz meglátni és nehéz elsajátítani, ezért mondtam, hogy a tanítványaimat oktatom, és miután a tanítványok megkapták a tanítást, egész életükben gyakorolják a tiszta életmódot, hogy másnak is el tudják magyarázni. Nigrodha, a te hagyományvonalad aszkézisével kapcsolatban kérdezz engem, biztosan fogok tudni válaszolni, és ez megelégedésedre lesz.' Ekkor a különféle más tanítású tömeg egyszerre kiabálni kezdett, nagy hangon kiáltottak: 'Milyen csodálatos Gotama szerzetes, milyen különleges! Hatalmas mágikus képessége van, óriási ereje, milyen áldott és milyen lenyügöző! Hogy miből látszik ez? Mert képes félretenni saját tanítását, és más tanítást 
követő személy kérdésére válaszolni.' Ezután Nigrodha lecsendesítette a tömeget, és ezt kérdezte: 'Gotama, az aszkézissel mennyire lehet elérni a tökéletességet és mennyire nem lehet elérni azt?"'

世尊知已，語曰：「無恚！我法甚深！甚奇！甚特！難覺難知， 難見難得, 謂我教訓弟子。弟子受教訓已，盡其形壽淨修梵行， 亦為他說。無恚! 若汝師宗所可不了憎惡行者, 汝以問我, 我 必能答, 令可汝意。」於是, 調亂異學眾等同音共唱, 高大聲 曰：「沙門賉昙甚奇！甚特！有大如意足，有大威德，有大福 祐, 有大威神。所以者何? 乃能自捨己宗, 而以他宗隨人所問

。」於是異學無恚自勅已眾，令嘿然已，問日：「睢曇！不了 可憎行，云何得具足? 云何不得具足? 」10

\section{III/1. ÁLTALÁNOS BEVEZETŐ (T01n0001: 散陀那經)}

„A Világ tiszteltje így szólt: 'Ó, aszkéták! A tanításom mély és átfogó, a kezdetektől oktatom tanítványaimat, hogy azok elérjék a megnyugvást, a tiszta életmódot, amit ti nem értek el.' És még ezt mondta az aszkétáknak: 'Teljes mértékben el tudom magyarázni viszont azt, ami az általatok, mesterek és tanítványok által gyakorolt útban tiszta és tisztátalan.' Ekkor az ötszáz aszkéta mindegyike megemelve a hangját így szólt egymáshoz: 'Gotama szerzetesnek nagy hatalma van, óriási szellemi ereje van, (hiszen) mikor más a tanításáról kérdezi, akkor a másik tanításáról magyaráz.' Ekkor Nigrodha aszkéta így szólt a Buddhához: 'Nagyszerü, Gotama! Szeretném, ha kifejtenéd.' Buddha így szólt az aszkétákhoz: 'Figyelemmel hallgassátok, figyelemmel hallgassátok, most kifejtem nektek.' Az aszkéták így válaszoltak: 'Örömmel hallgatjuk!','

世尊告曰：「且止！梵志！吾法深廣, 從本以來, 誨諸弟子, 得安隱處, 淨修梵行, 非汝所及。」又告梵志：「正使汝師及 汝弟子所行道法, 有淨不淨, 我盡能說。」時, 五百梵志弟子 各各舉聲, 自相謂言：「購曇沙門有大威勢, 有大神力, 他問 己義，乃開他義。」時，尼俱陀梵志白佛言：「善哉！睢曇！ 願分別之。」佛告梵志：「諦聽！諦聽！當為汝說。」梵志答 言 : 「願樂欲聞 ! 」11

T01n0026p0592a25-b06.

11 T01n0001p0047c06-14. 


\section{IV/1. ÁLTALÁNOS BEVEZETŐ (T01n0011: 尼拘陀梵志經)}

„Ekkor a Világ tiszteltje így szólt Nigrodha aszkétához: 'Nigrodha, ez a dolog valóban nehezen megismerhető. Hogy miért? Más a tanítás, más a nézet, más a tanító, más a gyakorlat, de inkább a saját tanításodból tegyél fel kérdést!' Ekkor az aszkéták hangosan kiabálva ezt mondták: 'Ez aztán a ritka dolog! Gotama aszkéta, amit tőle kérdeznek, azt nem a saját tanítása alapján válaszolja meg, hanem képes a másik tanításáról kérdést feltetetni, hogy aztán majd a megfelelő választ nyújtsa, bármi is a kérdés.' Ekkor Nigrodha aszkéta így szólt a Buddhához: 'Ha a mi tanításunk, nézetünk, mestereink és gyakorlatunk különbözik a te tanításaidtól és szabályaidtól, és nehéz lenne megismerni azokat, akkor most hadd tegyek fel a saját tanításomból kérdést neked: Hogyan kell ahhoz gyakorolni, hogy az ember képes legyen elérni a megszabadulást és tisztává váljék, hogy elérje a legtisztább állapotot, és elnyerje a végső gyümölcsöt [eredményt], és hogy képes legyen ebben a tisztaságban és a végső állapotban megmaradni?"”

爾時, 世尊告尼拘陀梵志言：「尼拘陀！汝於是事而實難知。 何以故? 異法、異見、異師、異行, 但應於汝自法教中隨應發 問。」是時, 諸梵志眾高聲唱言：「希有難有！沙門盽曇, 此 所問事, 不以自教而為見答, 返能於他教中令發問端, 隨問當 遣。」時, 尼拘陀梵志白佛言：「若我異法、異見、異師、異 行於汝法律, 我難知者, 我今於其自法教中請問於汝:云何修行 能得出離, 清淨得最上潔白, 及得真實, 得清淨真實中住? ${ }^{12}$

A páli és a három kínai fordítás összehasonlításakor nem lehet kétséges, hogy valóban ugyanarról a szövegről van szó: az alaphelyzet ugyanaz, az aszkéták társaságában lévő Nigrodha arra kéri Buddhát, hogy fejtse ki saját tanítását és gyakorlatát, de ezt Buddha annak nehézségére hivatkozva elutasítja, ugyanakkor készségesen válaszol egy olyan kérdésre, amely az aszkéták gyakorlatával kapcsolatos. Ezt a válaszát mindegyik forrásban a jelen lévő aszkéták hangos reakciója és csodálata kíséri, majd Nigrodha felteszi a kérdését, immáron a saját gyakorlatukra vonatkoztatva.

12 T01n0011p0223a09-18. 
Az alaphelyzet tehát azonos, a részletek azonban már különböznek. Elsőként a fenti egységekben meglévő neveket vizsgálom. Buddhának Gotama szerzetesként (Gotama szerzetes) való megnevezése minimális különbséggel jelenik meg mindegyik szövegben (T26, T0011: 沙門翟曇, T001: 翟昙 沙門), de Nigrodha neve már különbözik: két helyen fonetikus átírással találkozunk (T0011: Nijutuo 尼拘陀, T0001: Nijutuo 尼俱陀), míg a T0026-ban a fordítás szándékát látjuk, amikor „Haragnélküli”-ként (wu hui 無恚) adja vissza a személynevet. A valójában a banyan-fa (ficus indica) egyik nevével (p. nigrodha, sz. nyagrodha) összefüggő nevet a T0026 fordítója nyilván úgy értelmezte, hogy a szóban a fosztóképzőt (ni-, nir-, nis-) a 'harag' (p. kodha, sz. krodha) szó követi. Ez páliul azonban a Niggodha alak lenne, és nem a szanszkritos Nigrodha. ${ }^{13}$

Az aszkézisre vonatkozó páli kifejezés egyike (adhijeguccha, 'kerülés, lemondás, tartózkodás, tabu') Rhys Davids szerint mások lenézésére (jeguccha) utal, ${ }^{14}$ az ennek szinonimájaként használt tapojigucchā viszont már tartalmazza a tapa ('önsanyargatás, vezeklés, aszkézis', sz. tapas) ${ }^{15}$ szót. A SuttaCentral honlapon végzett keresés szerint az adhijeguccha a jelen szövegen kívül csak egyetlen másik helyen fordul elő, ${ }^{16}$ a Mahāsīhanādasuttában (DN 8.7), és meglepő módon ott is Nigrodhával összefüggésben: „Ott engem egy bizonyos Nigrodha nevü aszkéta az önsanyargatásról kérdezett” (Tatra maṃ aññataro tapabrahmacārī nigrodho nāma adhijegucche pañhạ̣ apucchi). Ez talán arra utal, hogy itt egy sajátos aszketikus formáról van szó, amely Nigrodhához és köréhez kötődik.

Míg a T0001 és a T0011 lényegében csak közvetett módon utal az aszkéták praxisára (suo xing daofa 所行道法, 'az általatok gyakorolt út és tanítás'; ru zi fajiao 汝自法教, 'a ti saját tanításotok'), addig a T0026 egy teljesen egyedi kifejezést (可不了憎惡行, illetve később többször 不了可憎行), amely egyértelmüen az előbbi páli kifejezéssel mutat párhuzamot (,rendkívüli mértékben utálatos/utálkozó magatartás"), amelyben a zeng'e 憎惡 ('gyülöl, utálkozik') a páli jigucchatihoz hasonló jelentésü. ${ }^{17}$ Mivel a páliban

13 Ez az észrevétel Ruzsa Ferencé (email, 2019.07.30).

14 Rhys Davids - Stede 1921-25 [2009]: 35: „intense scrupulous regard (for others)”; vö. Cone 2001/I: ,higher or superior scrupulousness”.

15 Rhys Davids - Stede 1921-25 [2009]: 333: „torment, punishment, penance, esp. religious austerity, selfchastisement, ascetic practice".

16 https://suttacentral.net/search?query=adhijeguccha (megtekintve: 2019. július 17.).

17 Rhys Davids - Stede 1921-25 [2009]: 319: „to shun, avoid, loathe, detest, to be disgusted with or horrified at." 
is sajátos az elnevezés, így a fordítók is különböző módon adják vissza a kifejezés jelentését. ${ }^{18}$

Magukat az aszkétákat a páli szöveg a paribbājaka szóval illeti, ami „vándort, vándorló koldust jelent”, ${ }^{19}$ addig ez a konkrét jelentése egyik kínai fordításban sem jelenik meg. Ez utóbbiak közül a T0001 és a T0011 a fanzhi 梵志 ('bráhmin, brahmacārin, aszkéta') szóval utal Nigrodhára és társaira, a T0026 ismét egészen más kifejezést használ a közösségre (yixue zhong 異學眾, „más tanításúak”, heterodoxok), illetve Nigrodhára (yixue 異學).

Buddha az aszkéták és közte meglévő különbségekre hivatkozva magyarázza inkább a másik, mint saját rendszerét. A páli szöveg itt öt különbséget sorol fel, míg a kínaiak közül csak a T11 említi ezeket, a sorrendjük azonban nem egyezik meg:

\begin{tabular}{|c|c|c|}
\hline & PÁLI & KÍNAI (T0011) \\
\hline más nézet & 1. añ̃̃adițthi & 2. yijian 異見 \\
\hline más álláspont & 2. añ̃akhanti & 1. yifa 異法 \\
\hline más hajlandóság & 3. añ̃̃aruci & - \\
\hline más gyakorlat & 4. aññatrāyoga & 4. yixing 異行 \\
\hline más mester & 5. añ̃atrācariya & 3. yishi 異師 \\
\hline
\end{tabular}

\section{Bevezető megjegyzések és étkezés}

\section{I/2. ÉTKEZÉS (DN 25)}

„Így, Nigrodha, az aszkéta ruha nélkül jár, szabadon viselkedik, a kezét megnyalja [evés után], nem megy, ha meghívják, nem marad, ha megkérik. Nem fogadja el, ha (ételt) visznek neki, ha (ételt) készítenek neki, ha (étkezéshez) hívják. Nem fogadja el, ha korsó szájából vagy edény

18 Például: ,,austere scrupulousness of life”, „higher forms of austere scrupulousness of life” (Rhys Davids) „higher mortification in disgust of sin” (Sujato); „eine hohe Abkehr" (Thalpawila Kusalagnana, Mudagamuwe Maithrimurthi, Thomas Trätowh), „le supreme austerità” (Enzo Alfano), „суровая аскетическая жизнь” (Леонид Шаповалов), a fordítások megtalálhatók a következő honlapon: https://suttacentral.net/ dn25, utoljára megtekintve 2019.07.18.

19 Rhys Davids - Stede 1921-25 [2009]: 479: ,a wandering man, a Wanderer, wandering religious mendicant, not necessarily Buddhist”. 
szájából (kínálják), ha (az adományozónak) kecskéje van, botja van vagy mozsártöröje van, ha ketten esznek, ha terhes vagy szoptat, ha férfi van otthon, ha ételosztás van, ${ }^{20}$ ahol kutya szolgál, ahol sok légy kering, nem (fogyaszt) halat, húst, részegítő italt, erjesztett italt, vagy kását. Egy házhoz (jár) vagy egy darab ételt eszik, két házhoz jár vagy két darab ételt eszik, (...) hét házhoz jár vagy hét darab ételt eszik. Egyszeri, kétszeri (...) vagy hétszeres adományból tartja fenn magát. Naponta egyszer eszik ételt, kétnaponta egyszer eszik ételt (...) hét naponta egyszer eszik ételt, így ilyen módon (akár) fél hónapot. Az ételek elfogyasztásának megszabott rendjét követve él. Növényeket eszik, gyógyfüvet eszik, vagy gabonát eszik, vagy vadrizst ${ }^{21}$ eszik, vagy daddularizst ${ }^{22}$ eszik, vagy az »úszó kagylótutaj « ${ }^{23}$ nevü növényt eszi, vagy korpát eszik, vagy a fővő rizs habját eszi, vagy szezámolajlisztet eszik, vagy füvet eszik, vagy tehénürüléket eszik. Az erdő (fáinak) gyökerével vagy gyümölcsével tartja el magát, a leesett gyümölcsöket fogyasztja."

Idha, nigrodha, tapassī acelako hoti muttâcāro, hatthâpalekhano, naehibhaddantiko, natiț̣habhaddantiko, nâbhihațam, na uddissakatam, na nimantanaṃ sādiyati, so na kumbhimukhā pațiggaṇhāti, na kaḷopimukhā paṭiggaṇhāti, na eḷakamantaraṃ, na dạ̣ḍamantaraṃ, na musalamantaraṃ, na dvinnaṃ bhuñjamānānam, na gabbhiniyā, na pāyamānāya, na purisantaragatāya, na saṅkittīsu, na yattha sā upațhito hoti, na yattha makkhikā sạ̣ḍasaṇụacārinī, na macchaṃ, na maṃsaṃ, na suram, na merayam, na thusodakam pivati, so ekāgāriko vā hoti ekâlopiko, dvāgāriko vā hoti dvâlopiko, sattāgāriko vā hoti sattālopiko, ekissâpi dattiyā yāpeti, dvīhipi dattīhi yāpeti, sattahipi dattīhi yāpeti; ekāhikampi āhāraṃ āhāreti, dvīhikampi āhāraṃ āhāreti, sattāhikampi āhāraṃ āhāreti, iti evarūpạ̣ addhamāsikampi pariyāyabhattabhojanânuyogamanuyutto viharati. So sākabhakkho vā hoti,

20 Rhys Davids - Stede (1921-25 [2009]: 735) szerint a sankittīsu szó jelentése kétséges. A fenti fordítás Ruzsa Ferenc egyik javaslatát (sam + kīrti) követi, a másik javaslat szerint a kifejezés az „összekevert ételmaradék”-ra (,sam $+k \bar{r}$ : 'össze-szór') utalna (email, 2019.07.30). A egyik kínai változatban mintha szerepelne az 'össze, együtt' (sam-) jelentés (T01n0001p0047c18: gòng shi jiā 共食家, 'együtt étkező család').

Nīvāra = „raw rice, paddy” Rhys Davids - Stede (1921-25 [2009]: 420).

Daddula = ,certain kind of rice” Rhys Davids - Stede (1921-25 [2009]: 351).

23 Hata $=$,a kind of water-plant, Pistia stratiotes" Rhys Davids - Stede (1921-25 [2009]: 805). 
sāmākabhakkho vā hoti, nīvārabhakkho vā hoti, daddulabhakkho vā hoti, hațabhakkho vā hoti, kaṇabhakkho vā hoti, ācāmabhakkho vā hoti, piññākabhakkho vā hoti, tiṇabhakkho vā hoti, gomayabhakkho vā hoti; vanamūlaphalâhāro yāpeti pavattaphalabhojī.

\section{II/2. ÉTKEZÉS (T01n0026: 優曇婆邏經)}

„Ekkor a Világ tiszteltje így válaszolt: 'Nigrodha, vannak olyan szerzetesek, aszkéták, akik meztelenek, ruha nélküliek, mások a kezüket használják ruhának, megint mások falevelekből készítenek ruhát, ismét mások gyöngyböl készítenek ruhát. Egyesek nem vesznek korsóval vizet, mások nem vesznek merökanállal vizet, nem esznek meg olyan ételt, amit késsel vettek el (valakitől), elraboltak, vagy amit kicsaltak (valakitől). Maguktól nem mennek, meghívást nem fogadnak el, nem jönnek arra kérésre (hogy gyere,) ó tiszteletreméltó uram, nem tartják jónak (az ételt,) ó tiszteletreméltó uram, nem maradnak (arra, hogy maradj,) ó tiszteletreméltó uram.'

Ha két ember eszik, közöttük nem esznek, nem esznek olyan házban, ahol terhes nő van, ahol kutyát nevelnek, ha egy házban trágya van és legyek jönnek rá, ott sem esznek. Nem esznek halat, nem esznek húst, nem isznak alkoholt, nem isznak romlott vizet, vannak, akik egyáltalán nem isznak, megtanulják, hogy ivás nélkül éljenek. Egyesek egy falást esznek, és ezzel az egy falással megelégszenek, mások két, három, négy, egészen hét falást, akik hét falással elégszenek meg. Valakik evéskor egyszer jutnak hozzá, mert az egyszeri adománnyal megelégszenek, mások kétszer, háromszor, négyszer, egészen hétszeres adományhoz jutnak hozzá, akik a hétszeres adománnyal elégszenek meg. Egyesek egyszer esznek egy nap, mert az egyszeri evéssel elégszenek meg, mások két, három, négy, öt, hat, hétnaponta, félhavonta vagy egy havonta esznek egyszer, mert (az ilyen) egyszeri evéssel elégszenek meg. Egyesek zöldséget esznek, mások füvet esznek, megint mások hántolt rizst ${ }^{24}$ egyesek vegyes árpát, mások daddularizst, megint mások durva ételeket. Egyesek olyan helyre mennek, ahol nincsenek (mezögazdasági) teendők és nem tevékenykedve élnek, mások gyökeret esznek, megint mások gyümölcsöket vagy maguktól lehullott gyümölcsöket."

24 Itt két változatban a fa-gyök 木 és az 'áldozni’ 祭 fonetikai elem jelenik meg, de egy harmadikban (T01n0026p0441c29) a valószínúbb jimi 穄米 ('hántolt rizs') összetétel. 
於是，世尊答曰：「無恚！或有沙門、梵志倮形無衣, 或以手 為衣, 或以葉為衣, 或以珠為衣。或不以瓶取水, 或不以槐取 水, 不食刀杖劫抄之食, 不食欺妄食, 不自往, 不遣信, 不求 來尊, 不善尊, 不住尊。若有二人食, 不在中食, 不懷姙家食, 不畜狗家食, 設使家有糞蠅飛來而不食。不噉魚, 不食肉, 不 飲酒, 不飲惡水, 或都無所飲, 學無飲行。或噉一 $\square$, 以一 為足, 或二、三、四, 乃至七口, 以七口為足。或食一得, 以 一得為足, 或二、三、四乃至七得, 以七得為足。或日一食, 以一食為足, 或二、三、四、五、六、七日、半月、一月一食, 以一食為足。或食菜茹, 或食稗子, 或食 [木*祭]米, 或食雜

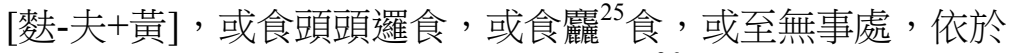
無事, 或食根, 或食果, 或食自落果。26

\section{III/2. ÉTKEZÉS (T01n0001: 散陀那經)}

„Buddha így szólt az aszkétához: 'Amit csináltok, az mind alávaló, leveszitek a ruhátokat és meztelenül jártok, kézzel takarjátok el magatokat. (Az aszkéták) nem fogadnak el ételt kancsóból, sem lapos edényböl, nem fogadnak el ételt két fal vagy két ember között, sem két kés vagy két edény között, nem fogadnak el ételt onnan, ahol együtt eszik a család, ahol terhes nő van a családban, ahol kutya van a kapuban vagy ahol sok légy van, továbbá ahol kérik, vagy ahol valaki más mondja, hogy elöre tudta ezt. Nem esznek halat és húst, nem isznak alkoholt, nem esznek két edényből. Egy étkezésnél egy falatot nyelnek le, egészen hét étkezésig, aminél megállnak. Elfogadják, ha az emberek többet adnak, de nem haladja meg a hétszeres (adagot). Egyesek egy nap egyszer esznek, mások kétnaponta, megint mások háromnaponta, négynaponta, ötnaponta, hatnaponta vagy hétnaponta esznek egyszer. Egyesek ismételten [állandóan] gyümölcsöt esznek, mások ismételten vadkölest, megint mások rizslét, kendert és rizst, nem ragacsos rizst, egyesek tehénürüléket esznek, mások őzürüléket esznek, egyesek a fák gyökereit, mások ágakat és leveleket, gyümölcsöket, megint mások saját maguktól leesett gyümölcsöket esznek."”

\footnotetext{
T01n0026_p0712b10:鹿.

T01n0026p0592b06-22.
} 
佛告梵志：「汝所行者皆為卑郖, 離服裸形, 以手障蔽, 不受 眪食, 不受孟食, 不受兩壁中間食, 不受二人中間食, 不受兩 刀中間食, 不受兩孟中間食, 不受共食家食, 不受懷妵家食, 見狗在門則不受其食, 不受多蠅家食, 不受請食, 他言先識則 不受其食; 不食魚, 不食肉, 不飲酒, 不兩器食, 一餐一咽, 至七餐止, 受人益食, 不過七益; 或一日一食, 或二日、三日、 四日、五日、六日、七日一食 ; 或復食果, 或復食莠, 或食飯 汁, 或食麻米, 或食稴稻, 或食牛糞, 或食鹿糞, 或食樹根、 枝葉、果實，或食自落果。27

\section{IV/2. ÉTKEZÉS (T01n0011: 尼拘陀梵志經)}

„Nigrodha, az általatok gyakorolt megszabadulásra irányuló cselekedetektől, mint a meztelenül levéstől, arra számítotok, hogy eléritek a megszabadulást. Olyan is van, hogy amikor valaki abbahagyja az ivást és az evést, megnyalja a kezét, hogy az tiszta legyen; nem fogad el ételt olyan embertöl, aki rosszallóan összevonja a szemöldökét vagy az arcán harag tükröződik; nem fogad el ételt az utcán és a sikátorokban; nem marad meg kések, botok és fegyverek között. Amikor a városban sétál körbe, visszafogott, hallgatag és nem beszél; nem mondja el, hogy honnan érkezett, nem mondja el, hogy hová tart, nem mondja el, hogy hol tartózkodik, száját nem hagyja el sem kellemes, sem kellemetlen szó, száját nem hagyja sokfajta beszéd, és nincs is semmi, amit szóban átadna.

Egyesek csak egy háztól fogadnak el ételt, mások két háztól, három háztól, egészen hét házig, megint mások kizárólag ugyanattól az egy háztól fogadnak el ételt, és más háztól nem. Egyesek egy nap napig nem esznek, mások két napig, három napig, egészen hét napig nem esznek, megint mások egy fél hónapban vagy egy hónapban esznek egyszer. Egyesek az ételek közül nem esznek rizslisztet, nem esznek fött rizst, nem esznek babot, valamint halat és húst, (nem fogyasztanak) tehéntejet, túrót, joghurtot, olajat, valamint mézet (stb.), nem isznak alkoholt, nem isznak édes kását és savanyú kását, kizárólag egyszerü, tiszta vizet,

27 T01n0001p0047c14-26. 
és azon élnek. Továbbá (egyesek) mindig zöldségeket esznek, mások füvet, egyesek tehéntrágyát ${ }^{28}$, mások gyógyfüvek palántáit vagy gyógyfüvek gyökerét, egyesek száraz vagy friss rizst vagy gabonát esznek, mások egyéb durva és visszataszító füveket és zöldségeket."

尼拘陀! 如汝所修出離行者, 謂裸露身體, 計得出離。又於飲 食事訖, 舐手取淨。不受頻威面人及瞋恚面人所施飲食; 不於 街巷中食; 不於刀杖兵器中住。周行城邑, 杜默不語、不說所 從來、不說所向詣、不說所住止、不出違順語、不出多種語, 亦無所說授。或受一家食 ; 或受二家三家乃至七家食 ; 或但受 一家, 不受餘家食。或一日不食 ; 或二日三日乃至七日, 或復 半月一月不食。或於食中, 不食其麨, 不食其飯, 不食豆及魚 肉、牛乳、酥、酪、油及蜜等, 不飲酒, 不飲甘漿, 不飲醋漿, 但飲糠粌清潔之水而為活命。又常食菜, 或食稊稗, 或食醀摩 夷, 或食藥苗、藥根, 或食乾生米穀, 或食諸餘麤惡草菜; ${ }^{29}$

A következő táblázatban összegeztem az egyes forrásokban megjelenő motívumokat:

\begin{tabular}{|c|c|c|c|}
\hline PÁLI & T01n0026 & T01n0001 & T01n0011 \\
\hline \multicolumn{4}{|c|}{ [BEVEZETÖ] } \\
\hline \multirow[t]{4}{*}{ meztelen } & meztelen & meztelen & meztelen \\
\hline & kezük a ruha & kezük a ruha & \\
\hline & levél a ruha & & \\
\hline & gyöngy a ruha & & \\
\hline \multicolumn{4}{|l|}{ szabad } \\
\hline \multirow[t]{2}{*}{ kezét megnyalja } & & & kezét megnyalja \\
\hline & nem megy magától & & \\
\hline nem megy hívásra & nem megy hívásra & & \\
\hline \multirow[t]{2}{*}{ nem marad kérésre } & nem marad kérésre & & \\
\hline & & & alig beszél \\
\hline
\end{tabular}

\begin{tabular}{|l|l|l|l|}
\hline \multicolumn{3}{|c|}{ [NEM FOGAD EL ÉTELT, HA:] } \\
\hline viszik neki & \multicolumn{3}{|c|}{} \\
\hline készítik neki & & & \\
\hline korsóból & korsó & kancsó & \\
\hline
\end{tabular}

\footnotetext{
28 A kínaiban itt egy fonetikusan átírt szó (qumoyi 睢摩夷, középkori kiejtéssel nagyjából go-ma-ji) szerepel, amely a páli/szanszkrit gomaya megfelelöje, és amely a másik szövegben (T01n0001p0047c24, T01n0001p0048a02) lefordítva szerepel (niufen 牛穓). 


\begin{tabular}{|c|c|c|c|}
\hline PÁLI & T01n0026 & T01n0001 & T01n0011 \\
\hline & merőkanál & & \\
\hline & rablott & & \\
\hline & kicsalt & & \\
\hline edényből & & edény & \\
\hline \multicolumn{4}{|l|}{ kecskéje van } \\
\hline \multirow[t]{2}{*}{ botja van } & & & botok között \\
\hline & & & fegyverek \\
\hline \multicolumn{4}{|l|}{ mozsártöröje van } \\
\hline & & két fal között & \\
\hline \multirow[t]{3}{*}{ ketten esznek } & ketten esznek & ketten esznek & \\
\hline & & két kés között & kések között \\
\hline & & két edény között & \\
\hline terhes & terhes & terhes & \\
\hline \multicolumn{4}{|l|}{ szoptat } \\
\hline \multicolumn{4}{|l|}{ férfi van otthon } \\
\hline [együtt esznek?] & & [együtt eszik a család] & \\
\hline kutya szolgál & kutyát tartanak & kutya a kapuban & \\
\hline \multirow[t]{6}{*}{ sok légy van } & a trágyán legyek & sok légy van & \\
\hline & & ahol megkérik & \\
\hline & & ahol megjósolják & \\
\hline & & & rosszalló \\
\hline & & & haragos \\
\hline & & & utcán, sikátorban \\
\hline
\end{tabular}

\begin{tabular}{|l|l|l|l|}
\hline \multicolumn{4}{|c|}{ [NEM FOGYSZT] } \\
\hline halat & halat & halat & halat \\
\hline húst & húst & húst & húst \\
\hline részegítő italt & alkoholt & alkoholt & alkoholt \\
\hline erjesztett italt & [alkoholt] & [alkoholt] & [alkoholt] \\
\hline kását & & & édes kását \\
\hline & & & savanyú kását \\
\hline & ivás nélkül él & két edényböl & \\
\hline & & & rizslisztet \\
\hline & & & fótt rizst \\
\hline & & & babot \\
\hline & & & tehéntejet \\
\hline & & & túrót \\
\hline & & & joghurtot \\
\hline & & & olajat \\
\hline & & & mézet \\
\hline & & &
\end{tabular}

\begin{tabular}{|l|l|l|l|}
\hline \multicolumn{4}{|c|}{ [HÁNY HÁZTÓL HÁNY FALAT] } \\
\hline $1-7$ házhoz jár & & $1-7$ házhoz jár \\
\hline $1-7$ falat ételt & $1-7$ falat ételt & $1-7$ falat ételt & \\
\hline $\begin{array}{l}1-7-\text { szeres } \\
\text { adomány }\end{array}$ & $\begin{array}{l}1-7 \text {-szeres } \\
\text { adomány }\end{array}$ & $\begin{array}{l}1-7 \text {-szeres } \\
\text { adomány }\end{array}$ & \\
\hline
\end{tabular}




\begin{tabular}{|c|c|c|c|}
\hline PÁLI & T01n0026 & T01n0001 & T01n0011 \\
\hline \multicolumn{4}{|c|}{ [14 nap alatt ESZIK:] } \\
\hline naponta & naponta & naponta & naponta \\
\hline \multirow[t]{5}{*}{ kétnaponta } & kétnaponta & kétnaponta & kétnaponta \\
\hline & háromnaponta & háromnaponta & háromnaponta \\
\hline & négynaponta & négynaponta & \\
\hline & ötnaponta & ötnaponta & \\
\hline & hatnaponta & hatnaponta & \\
\hline hétnaponta & hétnaponta & hétnaponta & hétnaponta \\
\hline \multirow[t]{2}{*}{$\begin{array}{l}14 \text { nap alatt } \\
\text { egyszer }\end{array}$} & 14 nap alatt egyszer & & 14 nap alatt egyszer \\
\hline & havonta egyszer & & havonta egyszer \\
\hline
\end{tabular}

\begin{tabular}{|l|l|l|l|}
\hline \multicolumn{5}{|c|}{ [KIZÁRÖLAG FOGYASZT:] } \\
\hline növényt & zöldséget & & zöldséget \\
\hline gyógyfüvet & & vadköles & gyógyfü palántája \\
\hline & & & gyógyfü gyökere \\
\hline gabonát & & rizst & gabonát \\
\hline vadrizst & hántolt rizst & $\begin{array}{l}\text { (száraz v. friss) } \\
\text { rizst }\end{array}$ \\
\hline & vegyes árpát & & \\
\hline daddula-rizst & daddula-rizst & & \\
\hline & & nem ragacsos rizs & \\
\hline & durva ételeket & & \\
\hline ,úszó kagylótutajt" & & & \\
\hline korpát & & kender & \\
\hline & & rizslé & \\
\hline fövő rizs habját & & & füvet \\
\hline szezámolaj-lisztet & & & tehénürüléket \\
\hline füvet & füvet & tehénürüléket & \\
\hline tehénürüléket & & özürüléket & \\
\hline & & gyökeret & \\
\hline fagyökeret & gyökeret & ágat & \\
\hline & & levelet & gyümölcsöt \\
\hline & & leesett gyümölcsöt & \\
\hline gyümölcsöt & gyümölcsöt & & \\
\hline leesett gyümölcsöt & leesett gyümölcsöt & \\
\hline & & & \\
\hline & & & \\
\hline
\end{tabular}

Érdemes azzal kezdeni, amiben a források megegyeznek. Az első jellemző, hogy a fontosabb kategóriák általában azonosak, tehát az egyes források megnevezik azt, hogy az aszkéták meztelenek, és hogy milyen esetekben nem fogadják el az ételt, ezután rátérnek arra, mit nem fogyasztanak, hány házhoz járnak, milyen gyakran esznek, illetve milyen típusú táplálékon élhetnek kizárólagosan. 
Az egyes kategóriákon belül a legpontosabb egyezés bizonyos tiltott ételek és italok esetében van (hal, hús, alkohol), illetve a fogyasztás gyakoriságán (bár a maximális időintervallum különbözik: egy hét, két hét vagy egy hónap). Az étel elfogadásának körülményei között bizonyos sajátos motívumok meglepően hasonlítanak (korsó, edény, terhes asszony, kutyák és legyek jelenléte), míg mások csak egy-egy forrásban találhatók. A szövegek megegyeznek abban, hogy egyik esetben sem magyarázzák el az adott szabály okát, csak a szabályt magát rögzítik. Az egyetlen kivétel a T0026 magyarázatnak tünő kitétele, amelyben a legyek jelenlétét az ürüléknek tulajdonítja, így míg a többi forrás csak a legyek sokaságát említi, addig a T0026 a legyek jelenlétének okát próbálja megvilágítani.

Ha a páli kifejtettségét összehasonlítjuk a kínai verziókéval, akkor azt láthatjuk, hogy bizonyos kategóriákat a T0026, másokat a T0001 taglal részletesebben, a T0011 pedig a nem fogasztandó ételek kategóriában számít a legrészletesebb forrásnak.

Az egyértelmü, hogy a kínai szövegek a páliból kimaradó részletekhez adalékul szolgálnak, hiszen megtudjuk, hogy levélből és gyöngyből is készült ruha, vagy egyesek nem fogyasztottak rizslisztet, babot, tehéntejet, túrót, joghurtot, olajat vagy mézet (amelyekre nincs utalás a többi forrásban), továbbá, hogy nemcsak a fák gyökerét, de ágát és levelét is megették. A fenti táblázatban hipotetikusan megfeleltettem bizonyos motívumokat, bár ezek nem egyértelmüek, például a páliban szereplő 'fővő rizs habját' (ācāma) a kínai rizslével (T0001: fanzhi 飯汁). Szintén érdekes, hogy bizonyos aszkéták esetében fontos szerepet játszó őz nem szerepel a páliban, és csak a T0001-ből tudjuk meg, hogy a leírás szerint az öz ürülékét (lufen 鹿糞) is fogyasztották, nem csak a tehénét.

Nehéz eldönteni, hogy például a részletezettség, illetve konkrétan az egyes szabályok megléte vagy hiánya összefügg-e azzal, hogy a páli a theravāda, a T0026 a sarvāstivāda, a T0001 pedig a dharmaguptaka hagyományt tükrözi, egy dolog azonban bizonyosnak tünik: ebböl a rövid részletből is tisztán látszik, amit majd a későbbiek is megerősítenek, hogy a négy szöveg négy különböző hagyományt képvisel, a három kínai verzió egyikét sem fordították a páliból vagy a pálival pontosan megegyező szanszkritból, továbbá úgy tủnik, hogy a kínai változatok között sincs két olyan szöveg, amely közvetlenül egy közös forrásra lenne visszavezethető. 


\section{3. Öltözködés}

\section{I/3. ÖLTÖZKÖDÉS (DN 25)}

„Durva kender ruhát hord, kevert kender ${ }^{30}$ ruhát hord, holttestet takaró ruhát hord, »szeméthalom《-ruhát hord ${ }^{31}$ lodhra ${ }^{32}$-fakéreg ruhát hord, fekete antilopbőr ruhát hord, fekete antilopbör köpenyt hord, kuśafüből $1^{33}$ készült öltözéket hord, fakéreg ruhát hord, favessző ruhát hord, emberi hajból készült ruhát hord, lófarokszőr ruhát hord, bagolyszárny ruhát hord."

So sāṇānipi dhāreti, masānāānipi dhāreti, chavadussānipi dhāreti, paṃsukūlānipi dhāreti, tirîtānipi dhāreti, ajinampi dhāreti, ajinakkhipampi dhāreti, kusacīrampi dhāreti, vākacīrampi dhāreti, phalakacīrampi dhāreti, kesakambalampi dhāreti, vāḷakambalampi dhāreti, ulūkapakkhampi dhāreti,

\section{II/3. ÖLTÖZKÖDÉS (T01n0026: 優曇婆邏經)}

„Egyesek egybefüggő ruhát hordanak, mások szőrruhát, megint mások vászonruhát, ${ }^{34}$ szőrrel (borított) vászonruhát, teljes állatbőrt, összekötött állatbőrt, teljes, összekötött állatbőrt."

或持連合衣, 或持毛衣, 或持頭舍衣, 或持毛頭舍衣, 或持全 皮, 或持穿皮, 或持全穿皮。 ${ }^{35}$

\section{III/3. ÖLTÖZKÖDÉS (T01n0001: 散陀那經)}

„Egyesek vállra vetett ruhát hordanak, mások vállra vetett füruhát, megint mások faháncsból készített ruhát, mások fükötényt vagy őzbőrt, egyesek kiengedik a hajukat (ruhaként), vagy (állat)szőrt kötnek össze, vagy temetői ruhát viselnek."

30 Rhys Davids - Stede 1921-25 [2009]: 583: ,a coarse cloth of interwoven hemp and other materials".

31 Ezt a buddhisták is hordták, a hagyomány szerint maga Buddha is (Strong 2004: 216).

32 Symplocos racemosa (Rhys Davids - Stede 1921-25 [2009]: 341).

33 Poa cynosuroides (Rhys Davids - Stede 1921-25 [2009]: 251).

34 A kínai toushe 頭舍 a páli dussa, illetve szanszkrit dūrśa / dūṣya szó átírása lehet, az előbbiről ld. Rhys Davids - Stede 1921-25 [2009]: 367: „woven material, cloth, turban cloth; (upper) garment, clothes”. Ugyanakkor a mao toushe yi 毛頭舍衣 kifejezés kétségessé teszi ezt. 


\section{$\ulcorner$ 或被衣, 或披莎衣, 或衣樹皮, 或草襜身, 或衣鹿皮, 或留 頭髮, 或被毛編, 或著塚間衣 ${ }^{36}$}

\section{IV/3. ÖLTÖZKÖDÉS (T01n0011: 尼拘陀梵志經)}

„Egyesek kizárólag egyetlen ruhát hordanak (hosszú ideig), mások füruhát viselnek, megint mások kuśafüből készült ruhát, faháncs ruhát, tủzifából készült ruhát, gyümölcsfaháncsból készült ruhát vagy halottégető helyeken ${ }^{37}$ szétszóródott hajból készült ruhát hord, vagy juhszőrt, szarvasszőrt, őzbőrt, tirīṭa $[\mathrm{ka}]^{38}$ madár szárnyából vagy füleskuvik szárnyából készült ruhát."

\section{或但著一衣, 或著草衣, 或著吉祥草衣, 或著樹皮衣, 或柴木 為衣, 或果樹皮為衣, 或以棄屍林中亂髮為衣, 或以羊毛, 鹿 毛、鹿皮為衣, 或以底哩吒鳥翅為衣, 或以鵂鶹翅為衣。39}

A lenti táblázatban összefoglaló jelleggel szerepelnek a fenti részletek információi:

\begin{tabular}{|c|c|c|c|}
\hline PÁLI & T01n0026 & T01n0001 & T01n0011 \\
\hline \multicolumn{4}{|l|}{ durva kender } \\
\hline \multicolumn{4}{|l|}{ kevert kender } \\
\hline holttestet takaró & & temetői & temetői hajból \\
\hline \multicolumn{4}{|l|}{ „Szeméthalom” } \\
\hline \multicolumn{4}{|l|}{ lodhra-fakéreg } \\
\hline fekete antilopbör & & őzbőr & özbör \\
\hline kusa-füből készült & & fükötény & kuśafü \\
\hline fakéreg & & faháncs & faháncs \\
\hline \multicolumn{4}{|l|}{ favessző } \\
\hline $\begin{array}{l}\text { emberi hajból } \\
\text { készült }\end{array}$ & & & kiengedett haj \\
\hline
\end{tabular}

T01n0001p0047c26-28.

37 A kínai kifejezés szó szerint: „liget, melybe a holttesteket kidobják” (qishilin 棄屍林). A holttest szó (shi 屍) szerepel egyébként az egyik híres halottégető hely, a szintén ligetként (lin 林) tételezett Sìtavana kínai átírásaiban is.

38 A dilizha 底哩吒 első két írásjegye a tri vagy tirī szótagot írja át, a második része több szótag átírása is lehet (ța, ta, ḍā, ḍa, țhi, ț̣a), ezek közül a tirīṭaka egy madár neve (bár az utolsó szótagja nincs meg a kínaiban). Ugyanez a név (vagy éppen az utolsó szótag nélkül: tirịṭa) egyben a korábban említett Lodhra-fának (Symplocos racemosa) a neve (Monier-Williams 1899: 448a). 


\begin{tabular}{|c|c|c|c|}
\hline PÁLI & T01n0026 & T01n0001 & T01n0011 \\
\hline \multicolumn{4}{|l|}{ lófarokszőr } \\
\hline bagolyszárny & & & füleskuvikszárny \\
\hline & egybefüggő & & \\
\hline & szőr & (állat)ször & \\
\hline & vászon & & \\
\hline & $\begin{array}{l}\text { szőrrel (borított) } \\
\text { vászon }\end{array}$ & & \\
\hline & teljes állatbőr & & \\
\hline & $\begin{array}{l}\text { összekötött } \\
\text { állatbőr }\end{array}$ & & \\
\hline & $\begin{array}{l}\text { teljes, összekötött } \\
\text { állatbör }\end{array}$ & & \\
\hline & & vállra vetett & \\
\hline & & vállra vetett fü & fü \\
\hline & & & egyetlen ruha \\
\hline & & & tüzifa \\
\hline & & & gyümölcsfa-háncs \\
\hline & & & juhszőr \\
\hline & & & szarvasször \\
\hline & & & tirīṭa $[\mathrm{ka}]$-szárny \\
\hline
\end{tabular}

A ruházatot illetően talán még nagyobb a diverzitás, mint az étkezésnél: létezik néhány elem a listán, amelyek hozzávetőlegesen egybeesnek: az antilopvagy őzbőr, a temetőből származó öltözék vagy a fakéreg öltözék például ilyenek, ahogy a bagoly-, illetve füleskuvikszárnyból készült ruha is. A többi elem ugyanakkor legfeljebb egy vagy két forrásban tünik fel, ami ismét arra tünik utalni, hogy a szövegek nem vezethetők vissza közvetlenül egy közös forrásra.

\section{Egyéb}

\section{I/4. EGYÉB (DN 25)}

„Kitépi a haját és a szakállát, a haj- és szakállkitépés gyakorlatát végzi. Egyenesen áll, elutasítja a leülést, guggol, a guggolás gyakorlatát végzi. Tövisszőnyegen fekszik, a tövisszőnyeget teszi meg ágyának, deszkát tesz meg ágyának, a puszta földet teszi meg ágyának, (csak) az egyik oldalán fekszik. Sarat visel (magán), a szabadban tartózkodik, (ott alszik,) ahol csak leteszi a szőnyegét. Szennyes dolgokat eszik, a szennyes ételek megevésének gyakorlatát végzi. Nem iszik, a nem ivás gyakorlatát végzi. Úgy él, hogy a vízben való háromszori megmerítkezés gyakorlatát végzi." 
Kesamassulocakopi hoti kesamassulocanânuyogamanuyutto, ubbhaț̣hakopi hoti āsanapațikkhitto, ukkuṭikopi hoti ukkuțikappadhānamanuyutto, kaṇțakâpassayikopi hoti kaṇtakâpassaye seyyạ̣ kappeti, phalakaseyyampi kappeti, thaṇiliaseyyampi kappeti, ekapassayikopi hoti. Rajojalladharo, abbhokāsikopi hoti yathâsanthatiko. Vekaṭikopi hoti vikațabhojanânuyogamanuyutto, apānakopi hoti apānakattamanuyutto, sāyatatiyakampi udakorohanânuyogamanuyutto viharati.

\section{II/4. EGYÉB (T01n0026: 優曇婆邏經)}

„Egyesek szabadon hagyják a hajukat, mások összefonják a hajukat, megint mások szabadon vagy összefonva hordják a hajukat. Egyesek levágják a hajukat, mások a szakállukat vágják le, megint mások levágják a szakállukat és a hajukat is. Egyesek kihúzzák a hajukat, mások a szakállukat húzzák ki, megint mások kihúzzák a szakállukat és a hajukat is. Vannak, akik állnak, elutasítják a leülést, valakik a guggolás tevékenységét gyakorolják, mások tövisen fekszenek, a töviseket teszik meg ágyuknak, megint mások gyümölcsön fekszenek, a gyümölcsöt teszik meg ágyuknak. Egyesek a vizet tisztelik, éjjel-nappal a kezükkel merik; mások a tüzet tisztelik, egész éjszaka ${ }^{40}$ égve $^{41}$ tartják; megint mások a Napot és a Holdat tisztelik, becsben tartják a hatalmas erényüket, a kezüket kulcsolják össze feléjük. Ekként mérhetetlenül sok szenvedést viselnek el, és a kínokkal teli életmódot sajátítják el."

或持散髮, 或持編髮, 或持散編髮, 或有剃髮, 或有剃䰅, 或 剃䰅髮, 或有拔髮, 或有拔䰅, 或拔䰅髮。或住立斷坐, 或修 蹲行, 或有臥刺, 以刺為床, 或有臥果, 以果為床。或有事水, 書夜手抒; 或有事火, 竟昔然之; 或事日月, 尊祐大德, 叉手向彼。如此之比, 受無量苦, 學煩熱行。42

40 Az itt kevéssé értelmes $x \bar{l}$ 昔 ('egykor, régen') szót a vele gyakran összekevert $x \bar{\imath}$ 夕 ('este') írásjegyként értelmeztem.

41 A rán 然 ('ekként, így, igen') szó helyett a rán 燃 írásjegy értelmét ('meggyújt') vettem, az egyik változatban (T01n0026p0712b18) egyébként így is szerepel: 竟昔燃之.

42 T01n0026p0592b24-c01. 


\section{III/4. EGYÉB (T01n0001: 散陀那經)}

„Egyesek mindig a magasba tartják a kezüket, mások nem ülnek le padra vagy gyékényre, megint mások állandóan guggolnak. Egyesek levágják a hajukat vagy meghagyják a hajukat és a szakállukat. Egyesek tövisen alszanak, mások gyümölcsön és dinnyén alszanak, megint mások meztelenül alszanak tehénürüléken. Egyesek egy nap háromszor fürdenek, mások egy éjjel háromszor. Mérhetetlenül sok kínnal gyötrik a testüket."

或有常舉手者, 或不坐牀席, 或有常蹲者, 或有剃髮留髦䰅者, 或有臥荊棘者, 或有臥果夰上者, 或有裸形臥牛糞上者; 或一 日三浴，或有一夜三浴；以無數眾苦，苦役此身。43

\section{IV/4. EGYÉB (T01n0011: 尼拘陀梵志經)}

„Amit ti gyakoroltok, azok (ilyenek): magas helyeken kóborolva megálltok és ülőhelyet készítetek; egyesek egyik lábukat felemelve állnak, és ezt vélik vallásos gyakorlásnak; mások állandó szenvedések közepette durva és rossz italokat és ételeket fogyasztanak, és ezt vélik vallásos gyakorlásnak; megint mások a szabadban mozdulatlanul maradnak, és ezt vélik vallásos gyakorlásnak; egyesek nem vágják le a szakállukat és a hajukat, és ezt vélik vallásos gyakorlásnak; mások tövisen fekszenek, és ezt vélik vallásos gyakorlásnak; megint mások összekötött szarufákon alszanak, és ezt vélik vallásos gyakorlásnak; egyesek egy állandó helyen tartózkodva jutnak el az égi magasságokig, és ezt vélik vallásos gyakorlásnak; másik egyetlen helyhez kötözik magukat, és ezt vélik vallásos gyakorlásnak; egészen azokig, akik naponta háromszor fürdenek. Ilyen sok fajta szenvedéssel gyötrik magukat, hogy magukban gyógyulást idézzenek elő, és ezt vélik vallásos gyakorlásnak.”

汝所修行, 謂高處遊止, 施設座位, 或䞨足而立, 以為法行; 或 常受苦澁麤惡飲食, 而為法行; 或寂止空地, 而為法行; 或不去 䰅髮, 而為法行 ; 或偃臥棘刺, 或臥編椽, 而為法行 ; 或居止常 處凌雲高顯, 而為法行; 或繫著一處, 而為法行, 乃至一日三時 沐浴其身。如是多種逼切苦惱, 治療於身, 而為法行。4 4

43 T01n0001p0047c28-a03.

44 T01n0011p0223a27-b05. 
A korábbiakhoz hasonlóan ismét egy táblázatban foglalom össze az egyes forrásokban szereplö motívumokat úgy, hogy az egymáshoz hasonlókat megfeleltetem.

\begin{tabular}{|c|c|c|c|}
\hline PÁLI & T01n0026 & T01n0001 & T01n0011 \\
\hline & $\begin{array}{l}\text { szabadon hagyja a } \\
\text { haját }\end{array}$ & meghagyja a haját & meghagyja a haját \\
\hline & & $\begin{array}{l}\text { meghagyja } \\
\text { szakállát }\end{array}$ & $\begin{array}{l}\text { meghagyja } \\
\text { szakállát }\end{array}$ \\
\hline & összefonja a haját & & \\
\hline & levágja a haját & levágja a haját & \\
\hline & levágja a szakállát & levágja a szakállát & \\
\hline kitépi a haját & kitépi a haját & & \\
\hline kitépi a szakállát & kitépi a szakállát & & \\
\hline áll, nem ül le & áll, nem ül le & nem ül le & \\
\hline & & & egy lábon áll \\
\hline guggol & guggol & guggol & \\
\hline tövisszőnyegen & töviságyon alszik & tövisen alszik & tövisen alszik \\
\hline & $\begin{array}{l}\text { gyümölcságyon } \\
\text { alszik }\end{array}$ & gyümölcsön alszik & \\
\hline deszkán alszik & & & szarufán alszik \\
\hline puszta földön alszik & & & \\
\hline egyik oldalán alszik & & & \\
\hline & & $\begin{array}{l}\text { meztelenül, } \\
\text { tehénürüléken }\end{array}$ & \\
\hline sarat visel (magán) & & & \\
\hline szabadban van & & & \\
\hline $\begin{array}{l}\text { szennyes dolgokat } \\
\text { eszik }\end{array}$ & & & $\begin{array}{l}\text { durva italok, } \\
\text { ételek }\end{array}$ \\
\hline nem iszik & & & \\
\hline $\begin{array}{l}\text { vízben } 3 \mathrm{x} \\
\text { merítkezik }\end{array}$ & & nappal 3x fürdik & $3 x$ fürdik \\
\hline & & éjjel 3x fürdik & \\
\hline & vizet tisztel & & \\
\hline & tüzet tisztel & & \\
\hline & $\begin{array}{l}\text { Napot, Holdat } \\
\text { tiszteli }\end{array}$ & & \\
\hline & & $\begin{array}{l}\text { kezét felemelve } \\
\text { tartja }\end{array}$ & mozdulatlan \\
\hline & & & meditál (?) \\
\hline & & & magát odakötözi \\
\hline
\end{tabular}

A fenti táblázatból nagyjából ugyanaz látszik, mint a korábbiakból: a kínai verziókban csak részlegesen látjuk a páli szövegben szereplő aszketikus gyakorlatok megfelelöit, illetve a kínai szövegekben számos helyen szerepelnek további elemek, amelyek a páliban nem pusztán konkrétan nem jelennek meg, 
de maga a kategória sem tünik fel (ilyen például a T0026-ban felsorolt vallásos tisztelet a víz, a tüz, a Nap és a Hold iránt). Vannak olyan példák, ahol a páli sajátos motívuma (pl. haj és szakáll kitépése) egyetlen szövegben megjelenik (szintén a T0026), de máshol nem. Alig találkozunk olyan motívummal, amely mind a négy forrásban jelen lenne (ilyen a tövisen fekvés vagy alvás, illetve kicsit tágabban értelmezve a folyamatos állás), és az öltözködés témájához hasonlóan alig van olyan motívum, amely akárcsak a három kínaiban pontosan megegyezne (ilyen a haj növesztése).

\section{Befejezés}

\section{I/5. BEFEJEZÉS (DN 25)}

„Mit gondolsz, Nigrodha, ha ezek így vannak, akkor az önsanyargatás tökéletes vagy tökéletlen?"

Taṃ kiṃ maññasi, nigrodha, yadi evaṃ sante tapojigucchā paripuṇṇā vā hoti aparipuṇnā vā’ti?

\section{II/5. BEFEJEZÉS (T01n0026: 優曇婆邏經)}

„Nigrodha, mit gondolsz erről, ha így végzik az önsanyargatást, akkor az tökéletes vagy tökéletlen?"

無恚! 於意云何? 不了可憎行如是, 為具足 ? 為不具足 ?」45

\section{III/5. BEFEJEZÉS (T01n0001: 散陀那經)}

„Nigrodha, akik ekként cselekszenek, nevezhetjük őket tiszta tanításúaknak, vagy sem?”

$\left\ulcorner\right.$ 云何? 尼俱陀! 如此行者, 可名淨法不 $?{ }^{46}$

T01n0026p0592c02-03.

46 T01n0001p0048a03-04. 


\section{IV/5. BEFEJEZÉS (T01n0011: 尼拘陀梵志經)}

„Az ilyen jellegü cselekedeteket, te, Nigrodha aszkéta, olyannak gondolod, amelyek megszabadítanak. Nigrodha, ezek a cselekedetek vajon meghozzák gyümölcsüket, hogy az ember elérje a megszabadulást, és tisztává váljék? Eléri vajon a legmagasabb tisztaságot? Elnyeri a végső gyümölcsöt? És képes lesz ebben a tisztaságban és valódi gyümölcsben megmaradni?"

如是等事, 是汝尼拘陀修行者, 計為出離之行。「尼拘陀! 此 等所行而還實得出離清淨邪? 得最上潔白邪? 得真實邪? 得清 淨真實中住邪? 」47

Ezekben a tematikus egységet lezáró és a következő részt megnyitó részletekben közös elem, hogy az egység elején feltett kérdést ismétli meg, bár ez a kérdés már az első helyen is kissé másra irányult: a páli és a T0026 a tökéletességre, míg a T0001 és a T0011 a tisztaságra.

\section{További különbségek a három kínai verzió között}

A fentiekben lényegében kizárólag az aszkézis különféle változataira koncentrálva hasonlítottam össze a páli és a három kínai verziót. Az eredményt röviden összefoglalva arra jutottunk, hogy bár elméletileg ugyanarról a szuttáról van szó, a benne konkrétan megnevezett aszketikus gyakorlatok jelentős mértékben különböznek egymástól, amit alapvetően ezek különböző irányzati (theravāda, sarvāstivāda, dharmaguptaka) hátterének tulajdonítok. A következőkben röviden bemutatom, hogy az itt talált legfontosabb eredmény, tehát hogy itt valójában négy hagyomány egymástól jelentős mértékben különböző verzióival van dolgunk, nemcsak erre a részre, de a szutta egészére is igaz.

Ezúttal is érdemes a nevekkel kezdeni. Azt már az írás elején megállapítottuk, hogy Buddha neve (Gotama, Qutan 矍昙) azonos mindhárom kínai változatban, hasonlóképpen Rājagaha, amelyet mindhárom kínai szöveg királyi lakhelynek, városnak (Wangshecheng 王舍城) fordít, de ebben a két, általános névben lényegében ki is merült a három szöveg közötti azonosság. A fontosabb szereplők közül nemcsak Nigrodha (T0011: Nijutuo 尼拘陀, T0001: Nijutuo 尼俱陀, T0026: Wuhui 無急), de a kerettörténet másik fösze-

47 T01n0011p0223b25-28. 
replöjének, Sandhānának a neve is három változatban jelenik meg: Hehe 和合 (T0011), Santuona 散陀那 (T0001), Shiyi 實意 (T0026). Ezek közül a középső fonetikus átírás, a másik kettő pedig értelmező jellegü fordításnak tünik ('Harmonikus összhang; Igaz szándék'). A Nigrodhához hasonlóan szintén egy fáról (udumbara, Ficus glomerata) elnevezett Udumbarikā, a szálláshelyet fenntartó hölgy neve, szintén három különböző változatban tünik fel (mindhárom fonetikus átírás): Wutanmoli 烏曇末梨 (T0011), Wuzanpoli 烏暫婆利 (T0001); Youtanpoluo 優昙婆邏 (T0026).

A neveken túl számos különbség található a szutta szerkezetében és motívumaiban is, kezdjük itt is egy kokrétummal. A páli változat az aszkéták összegyülekezett csoportjáról beszél (paribbājakaparisā), akik háromezren voltak. A T0011, amely szerint aszkéták vették körbe (與諸梵志圍繞而住), a másik két kínai szöveg ugyanakkor 500-ban pontosítja az aszkéták létszámát (T0001: 五百梵志子; T0026: 五百異學).

Az események szintjén is számos eltérést tapasztalhatunk. A T0001-ben miután Buddha meghallja a Sandhāna és Nigrodha közötti beszélgetést, egyenesen a vándorok lakhelyére megy Udumbarāba, míg a páli változatban és a T0011-ben először a Sumāgadhā partján sétáló meditációt végez, és hagyja, hogy Nigrodha megszólítsa. A páli változatban Nigrodha alig várja, hogy Buddha megérkezzen, és feltehesse neki a kérdését, a T0001-ben azonban azt mondja társainak, hogy ne menjenek elé, és ne kínálják hellyel (ez feltűnően hasonlít a Benáreszi beszéd elején megjelenő aszkéták attitüdjéhez): „Ekkor, (Nigrodha) aszkéta messziről meglátta, hogy Buddha jön, és ezt az utasítást adta tanítványainak [a többi aszkétának]: 'Hallgassatok el, Gotama szerzetes jön erre, de vigyázzatok, nehogy elé menjetek, hogy fogadjátok őt, vagy tiszteleteteket fejezzétek ki neki, nehogy megkínáljátok hellyel!",48

Három változatban Buddha csak az aszkétákról szóló első rész után kezdi el fokozatosan rávezetni Nigrodhát, hogy az aszkézis önmagában még elégtelen, ennél sokkal többre van szükség, de a T0011-ben (p0223a18-26) már a beszéde legelején előre elmondja saját magával kapcsolatban a négy tökéle-

48 T01n0001p0047b21-26: 時, 彼梵志遙見佛來, 勅諸弟子：「汝等皆默, 矍昙 沙門欲來至此, 汝等慎勿起迎、恭敬禮拜, 亦勿請坐... Hasonlóan fogalmaz a T0026 is: „Ekkor a 'más tanítású' Nigrodha így szólt a közösségéhez: 'Tiszteletreméltók, Gotama szerzetes jön a mi közösségünkbe, amikor idejön, ne tiszteljétek, ne keljetek fel a helyetekröl, ne tegyétek össze a kezeteket felé, ne kínáljátok hellyel...!” (T01n0026p0592a05-9 || 於是，異學無恚告己眾曰：「諸賢！沙門 翟昙儻至此眾, 若必來者, 汝等莫敬, 從坐而起, 叉手向彼, 莫請令坐 $\cdots$ 」 
tességet (si jie juzu 四戒具足), és csak ezek után tér rá Nigrodha aszkézisére. A páli változatban Nigrodha már a beszéd közben fokozatosan elismeri, hogy nem tökéletes az aszkézis útja, míg a T0011-ben Buddha magyarázata közben Nigrodha továbbra is folyamatosan ragaszkodik ahhoz, hogy az ö útja is helyes, és azzal is elérhető a megmagasabb cél: „Nigrodha aszkéta így szólt Buddhához: 'Gotama szerzetes, habár amit mondasz, az nagyon helyes, de ahogy én csinálom, ezzel (is) meg lehet szabadulni és meg lehet tisztulni, ez (is) elvezet a végső eredményre, ezzel (is) el lehet érni a felülmúlhatatlant."

A páli szutta vége felé Buddha fokozatosan lecsökkenti azon időszakot, amennyi alatt képes lenne az aszkétáknak átadni saját tudását, végül a minimális időszakot hét napban állapítja meg. A T0011-ben ugyanez egy fél nappá zsugorodik, ${ }^{50}$ míg a T0026-ban erről egyáltalán nincs szó, a teljes rész kimarad.

A szutta vége felé, amikor Nigrodha már felismerte Buddha beszédének igazságtartalmát, de a többi aszkéta nem igazán hajlandó változtatni a hozzáállásán, a páliban Buddha magában gondolja azt („Atha kho bhagavato etadahosi”), hogy az aszkétákat Mára szállta meg, miközben mindhárom kínai fordításban Sandhānának mondja mindezt. ${ }^{51}$

A szutta lezárásánál a páli verzióban Buddha a levegőbe emelkedik, és úgy tér vissza a Keselyü-csúcsra, de ezen kívül más csoda nem történik. A T0011ben Buddha teste elkezd ragyogni, fényt bocsát ki, majd ezután következik a levegőbe emelkedés és a visszatérés. ${ }^{52}$ A T0001-ben Buddha jobb kezével megfogja Sandhānát, és együtt repülnek vissza, az aszkéták pedig mind örvendenek, hogy hallhatták Buddha tanítását. ${ }^{53}$ A T0026-ban Buddha szintén Sandhāna kezét megfogva emelkedik a levegőbe, de egyrészt nincs arról szó, hogy merre mennek, másrészt a szöveg azt emeli ki, hogy Sandhāna örvendezett azon, hogy hallhatta Buddha tanítását, és az aszkétákról már nem esik szó. ${ }^{54}$

Véleményem szerint e néhány részletben tapasztalt különbség, továbbá hogy nincs okunk kételkedni abban, hogy a kínai verziók mindegyike egyegy korábban meglévő, indiai (feltehetőleg szanszkrit vagy szanszkritizált

\footnotetext{
49 T01n0011p0224a10-12: 尼拘陀梵志白佛言：「沙門瞿曇！如汝所說, 雖為 甚善。然我此修行, 是得出離清淨, 是得真實, 是得無上。」

T01n0011p0226b08-11.

T01n0011p0226b16; T01n0001p0049b20; T01n0026p0595c01-2.

T01n0011p0226b22-24.

T01n0001_p0049b22-25.

T01n0026p0595c05-9.
} 
középind) nyelvü, mára elveszett eredetinek a viszonylag pontos fordítása, mindez tehát megerősíti azt a konklúziót, amelyre a részletesebben elemzett aszketikus praxis leírásával is jutottunk, tehát hogy jelenleg ugyanannak a szuttatörténetnek és beszédnek négy különböző, egymással közvetlenül össze nem függő változata áll a rendelkezésünkre.

A szövegből nyilvánvaló, hogy az aszketikus gyakorlatok részletekbe menő leírása itt pusztán arra szolgál, hogy Buddha bemutassa a róluk kialakított általános véleményét, tehát a listák bármelyik eleme tetszés szerint elhagyható, sőt teljes kategóriák is mellőzhetők (mint ahogy ez meg is történik). A négy változat, valamint a hasonló jellegü szövegek azt mutatják, hogy nem egyetlen, rendelkezésre álló listát illesztettek be a különböző szuttákba, amikor az aszkéták ügye volt terítéken, hiszen még ugyanannak a szuttának a különböző verzióiba sem ugyanaz a lista került. Mivel az érvelés szempontjából lényegtelen volt, hogy az aszkézis széles tárházából éppen milyen elemet vesznek elő, így legalább két megoldás adódik:

1. A páli és a kínai változatokban tükröződő indiai eredetik pusztán irodalmi listákat tartalmaznak, vagyis a szövegek összeállítói a történeti valósággal semmilyen kapcsolatban nem lévő, az aszkéták különös szokásait illusztráló teljes, de valószínúleg ebben a formában soha le nem írt listájából szemezgetnek véletlenszerủen vagy az adott szöveghagyomány rendelkezésére álló módon.

2. Feltéve, hogy az aszkézisleírásokban megjelenő gyakorlatok jelentős része talán történetileg is létezhetett, a szövegek összeállítói elméletileg figyelembe vehették, hogy az összeállításuk idején és helyén az adott listából mely elemek tünhettek életszerünek, tehát egy aktuális buddhista közösség számára meggyőzőnek.

A választóvonal tehát az a kérdés, hogy itt egy teljesen fiktív, esetleg a szövegek keletkezése előtti távoli múltban létező, de a későbbiekben kivesző hagyományról van szó, vagy mindezen gyakorlatoknak (vagy legalább egy részük) történetileg is létezett a szövegek keletkezésekor. Jelenlegi ismereteim szerint magam részéről az utóbbi felé hajlok, hozzátéve, hogy természetesen az is valószínü, hogy a listák e kettő (irodalmi motívumok és történeti valóság) bizonyos arányú keverékei lehetnek.

Amennyiben tehát a gyakorlatoknak legalább egy jelentős része történetileg is létezett, így nincs akadálya annak, hogy feltegyük, az adott irányzat bizonyos értelemben figyelembe vette a történeti realitást, és a listát az adott szöveg keletkezési ideje és helye szerint módosította, amelyet könnyen megtehetett a fent említett okból (tehát hogy a lista egyes elemeinek megléte 
vagy hiánya teljes mértékben közömbös a buddhai érvelés szempontjából). Az irodalmi toposzok kényszerítő erejét leszámítva, a szöveg belső logikája megengedhetett egy ilyen jellegü történeti adaptációt.

A páli szöveg és a több példányban fennmaradt kínai verziók alaposabb vizsgálata a későbbiekben fényt deríthet arra, hogy a különböző korai irányzatokhoz tartozó szövegek milyen jellegzetességekkel bírtak, mennyire különböztek egymástól, illetve hogy összeállítóik mennyiben próbálták esetleg koruk történeti realitásához igazítani a szövegek tartalmát. Ez utóbbihoz nyilvánvalóan érdemes lenne megvizsgálni a theravāda, a sarvāstivāda és a dharmaguptaka irányzatokhoz tartozó szövegekben szereplő egyéb aszkétalistákat, és hogy ezek mutatnak-e valamilyen szabályszerüséget, de ez az elemzés már túllépné a jelen tanulmány kereteit.

\section{Felhasznált szakirodalom}

Anālayo 2011. A Comparative Study of the Majjhima-nikāya. Vols. I-II. Taipei: Dharma Drum Publishing Corporation.

Anālayo 2017. „The 'School Affiliation' of the Madhyama-āgama”. In: Dhammadinnā (ed.) Research on the Madhyama-āgama. Taipei: Dharma Drum Publishing Corporation, 55-76.

Choong, Mun-keat 2005. „The importance of Pali-Chinese comparison in the study of Pali suttas". Khthonios: A Journal for the Study of Religion (Queensland Society for the Study of Religion) II/2: 19-26.

Cone, Margaret 2001. A Dictionary of Pāli. Vols. I-II. Oxford: The Pali Text Society.

Hartmann, Jens-Uwe 2014. „The Dīrgha-āgama of the (Mūla-)Sarvāstivādins: What was the Purpose of this Collection?". In: Dhammadinnā (ed.) Research on the Dirghaägama. Taipei: Dharma Drum Publishing Corporation, 135-166.

Karashima, Seishi 2017. „The Underlying Language of the Chinese Translation of the Madhyama-āgama". In: Dhammadinnā (ed.) Research on the Madhyama-āgama. Taipei: Dharma Drum Publishing Corporation, 197-207.

McGovern, Nathan 2019. The Snake and the Mongoose. The Emergence of Identity in Early Indian Religion. Oxford: Oxford University Press.

Monier-Williams, Monier [rev. by E. Leumann, C. Cappeller et al.] 1899. A SanskritEnglish Dictionary: Etymologically and Philologically Arranged with Special Reference to Cognate Indo-European languages. Oxford: Clarendon Press.

Rhys Davids, C. A. F. - Stede, William 1921-25 [2009]: Pali-English Dictionary. Chipstead: Pali Text Society.

Strong, John 2018. Relics of the Buddha. Princeton: Princeton University Press. 